Gi respons på artikler gjennom artiklenes kommentarfelt på tidsskriftet.no.

Innleggene publiseres fortløpende på Tidsskriftets nettside og et utvalg

av innleggene publiseres også i papirutgaven i spalten «Brev til redaktøren».

Redaksjonen forbeholder seg retten til å foreta redaksjonelle endringer.

Forfattere av vitenskapelige artikler har tilsvarsrett, jf. Vancouver-gruppens regler

I debattartikkelen Nye sepsiskriterier kan føre til forsinket behandling publisert 24. april 2017 reiste S. Konradsen og A. H. Lien spørsmål ved om de nye qSOFA-kriteriene til bruk ved sepsis, kan føre dårligere pasientbehandling.

\section{qSOFA och tidig identifiering av sepsis}

qSOFA är en algoritm som skall identifiera $80 \%$ av patienter med sepsis och risk för «poor outcome», död under vårdtiden eller behov av intensivvård $\mathrm{i}>3$ dagar (1). Våra egna, ännu opublicerade, data av misstänkt samhällsförvärvad sepsis under 9 månader, visar att qSOFA identifierar $55 \%$ av 273 patienter med «poor outcome». qSOFA rekommenderas att användas utanför intensivvårdsavdelningar för att identifiera patienter som behöver utvärderas ytterligare avseende organdysfunktion orsakad av sepsis. Är detta en bra rekommendation? I en svensk studie identifierar qSOFA endast $55 \%$ av patienter med traditionell «svår sepsis» och endast $42 \%$ av patienter med «sepsis» enligt de föreslagna nya kriterierna, +2 poäng i SOFAscore (2). I samma studie identifierar $>2$ SIRS-kriterier 90 respektive $91 \%$ av patienter med svår sepsis eller sepsis enligt de nya kriterierna, Sepsis-3. I huvudartikeln om «Sepsis-3» skriver man: «The task force wishes to stress that SIRS criteria may still remain useful for the identification of infection» (3). Så, SIRS-kriterierna är fortfarande till stor hjälp för tidig identifiering av sepsis.

\section{Lars Ljungström}

lars.ljungstrom@vgregion.se

Lars Ljungström er overlege ved Infektionskliniken, Skaraborgs Sjukhus i Skövde, Sverige.

Ingen oppgitte interessekonflikter.

\section{Litteratur}

1. Seymour CW, Liu VX, Iwashyna TJ et al. Assessment of Clinical Criteria for Sepsis: For the Third International Consensus Definitions for Sepsis and Septic Shock (Sepsis-3). JAMA 2016; 315: 762-74.

2. Mellhammar L, Wullt S, Lindberg $\AA$ et al. Sepsis Incidence: A Population-Based Study. Open Forum Infect Dis 2016; 3: ofw207.

3. Singer M, Deutschman CS, Seymour CW et al. The third international consensus definitions for sepsis and septic shock (sepsis-3). JAMA 2016; 315: 801-10.

M. S. Næss stilte i artikkelen Hjelper antidepressiver mot depresjon? i Tidsskriftet nr. 9/2017 spørsmålet om han som nyutdannet lege bør forskrive antidepressiver til sine pasienter. Les et utdrag av debatten her, og resten på våre nettsider.

\section{Debatten om SSRI bør omhandle hvem som har utbytte av disse}

Antidepressive legemidler har ingen klinisk meningsfull effekt hevder Morten Svendsen Næss i Tidsskriftet nr. 9/2017. Hvis noen blir bedre ved behandling med SSRI er det fordi «pillene ikke fratok pasienten muligheten til å bli bedre» (1). Som støtte for sine påstander henviser han til Kirschs og medarbeideres publikasjon fra 2008 (2) som mener at SSRI kun har en svak effekt, og da bare hos de mest deprimerte pasientene. Næss siterer ikke svenske legemyndigheter som inspirert av Kirsch, analyserer antidepressiver godkjent i Sverige og på dette grunnlag konkluderer med at SSRI - i motsetning til hva Kirsch og medarbeidere påstår - har en klinisk betydningsfull effekt (3).

Som støtte for sitt syn henviser Svendsen også til en dansk metaanalyse (4). Forfatterne av denne metaanalysen finner at SSRI er bedre enn placebo, men tolker forskjellen som små. Men Svendsen omtaler ikke studiens metodeproblemer. De viktigste er kanskje at forfatterne ikke vekter studier ut fra kvalitet og definerer effekt kun ut fra effektstørrelser $>0.5$ basert på reduksjon av globalskala for depresjon (Hamilton). Men pasienter og klinikere er opptatt av global bedring som er langt mer enn en sumskår på en skala. Global bedring er blant annet relatert til effekt på nøkkelsymptomer som for eksempel pessimistiske tanker, depressive symptomer og initiativløshet samt søvn. Totalskår på Hamilton er ikke så relevant ut over at myndigheter bruker $50 \%$ reduksjon som kriterium for å akseptere effekt. HAM-D måler dessuten ikke én dimensjon og heller ikke nødvendigvis samme dimensjon i løpet av en behandling (5). Svendsen og andres ensidige fokus på en globalskår er således utdatert (6) og misvisende som eneste kriterium for klinisk effekt.

Betydningen av reduksjon i totalskår versus effekt på nøkkelsymptomer kan illustreres ved henvisning til den norske randomiserte og placebokontrollerte undersøkelsen av SSRI brukt i allmennpraksis (hvor prosjektleder ble lønnet av UiO og Oslo universitetssykehus og forskerne, ikke firmaet, eier data og publiserte disse). Forskjellen i reduksjon i en graderingsskala for depresjon (MADRS) mellom SSRI og placebo var 2.4 (7) hvilket ifølge Svendens kilder ikke er relevant klinisk effekt. Men effektstørrelsene av SSRI i forhold placebo var 0.59 for søvn og 0.54 for pessimistiske tanker hvilket er klinisk relevant ifølge de samme kilder. Effektstørrelsene var for øvrig 0.47 for selvrapportert depresjon og 0.36 for initiativløshet (8). Tar man i betraktning at mange av pasientene kun hadde sub-terskel depresjoner iflg. DSM-IV, er dette effektstørrelser av klinisk betydning.

Svendsen skriver også at ifølge det digitale oppslagsverket UpToDate tilskrives den lille fordelen i favør antidepressiver over placebo blant deprimerte pasienter delvis uspesifikke kliniske effekter av placebobehandling. Det kan for en leser forstås dit hen at UpToDate deler Svendsens syn på at SSRI ikke har klinisk signifikant effekt ved depresjoner. Det stemmer ikke. UpToDate oppsummerer sine vurderinger slik: «Antidepressants have demonstrated efficacy for major depression in patients treated by primary care clinicians», og de anbefaler SSRI som et aktuelt behandlingsalternativ for depresjoner (9).

Svendsen gjør ellers et nummer av at mange industrisponsrede studier i de senere år har vist manglende effekt uten å drøfte mulige årsaker til dette. Foruten pasientutvalg, kan en årsak være svak reliabilitet. Mens vi i den norske undersøkelsen kun aksepterte behandlere som oppnådde høy reliabilitet ved vurdering av depresjoner ved hjelp av MADRS (ICC? 0.7), har de fleste industrisponsrede studier ikke lagt inn slike krav. En amerikansk analyse av de best designede undersøkelsene sponsret av NIMH, hvor blant annet høy interbedømmerreliabilitet er påkrevet, fant en sterk effekt av SSRI brukt til behandling hos unge med depresjoner, mens industrisponsrede studier ikke har funnet effekt (10).

Man kan også få inntrykk av at Svendsen mener at manglende publisering av negative studier er noe som kun gjelder psykofarmakologistudier sponsret av industrien. Det er ikke riktig. Antallet negative psykoterapistudier som ikke publiseres er like omfattende (11).

Min vurdering er at debatten om SSRI har kliniske effekter ikke lenger er meningsfull. Det viktigste for oss som behandler depresjoner er å vite hvem som kan ha nytte av SSRI mot depresjoner, hvem som blir bra kun med støtte og problemløsningsstrategier eller hvem som kan bli bra med spesifikk psykoterapi.

\section{Ulrik Fredrik Malt}

u.f.malt@medisin.uio.no 